\title{
MOBİLYA SEKTÖRÜ ÇALIŞANLARINDA FİZIKSEL ZORLANMANIN BELİRLENMESİ
}

\author{
Velittin Kalınkara $^{1^{*}}$, Kadir Özkaya ${ }^{1}$, Olcay Polat ${ }^{2}$ \\ 1Pamukkale Üniversitesi, Denizli Teknik Bilimler MYO, Malzeme ve Malzeme İşl. Tekn. Böl., Denizli, Türkiye \\ 2Pamukkale Üniversitesi, Mühendislik Fakültesi, Endüstri Mühendisliği Bölümü, Denizli, Türkiye
}

\begin{tabular}{|c|c|}
\hline Anahtar Kelimeler & Özet \\
\hline $\begin{array}{l}\text { Mobilya endüstrisi, } \\
\text { Çalışma koşulları, } \\
\text { Fiziksel zorlanma, } \\
\text { Ergonomi. }\end{array}$ & 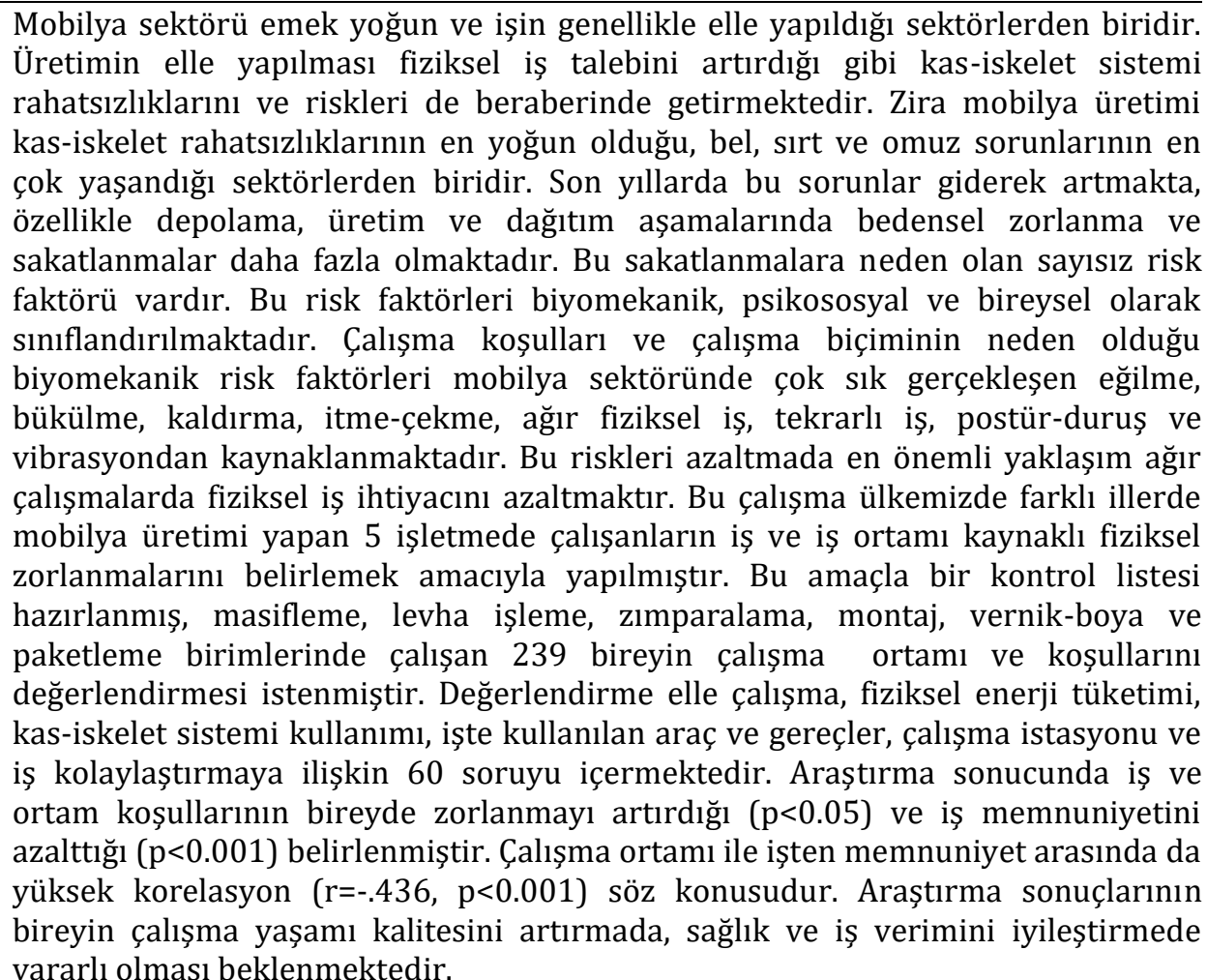 \\
\hline
\end{tabular}

THE DETERMINATION OF PHYSICAL STRAIN AT FURNITURE INDUSTRY WORKERS

\author{
Velittin Kalınkara' ${ }^{1 \dagger}$, Kadir Özkaya ${ }^{1}$, Olcay Polat ${ }^{2}$ \\ ${ }^{1}$ Pamukkale University, Denizli Vocational School of Technical Sciences, Department of Materials and Materials \\ Processing Technology, Denizli, Türkiye \\ ${ }^{2}$ Pamukkale University, Engineering Faculty, Department of Industrial Engineering, Denizli, Turkey
}

\begin{abstract}
Keywords
Abstract

Furniture industry,

Working conditions, Pphysical strain, Ergonomics.

\footnotetext{
* ilgili yazar: vkalinkara@gmail.com, +90-258-212-3788

${ }^{\dagger}$ Corresponding Author: vkalinkara@gmail.com, +90-258-212-3788
}

The furniture industry is one of the labour - intensive and generally the hand made working industries. The production to be done by hand as well as increases the physical work demands, it also brings with musculoskeletal system diseases and risks. Therefore, furniture manufacture is one of the sectors that musculoskeletal disorders are intense and it is one of the most experiencing 
sectors for lumbar, back and shoulder problems. In recent years, these problems have been increasing and especially physical strain and injuries have occurred more often in stages of storage, production and distribution. Many risk factors cause these injuries. These risk factors are classified as biomechanical, psychosocial and individual. The biomechanical risk factors caused by working conditions and working manner are due to bending, twist, lifting, pushing - pulling, heavy physical work, repetitive work, posture and vibration that occur very frequently in the furniture industry. The most important approach to reduce these risks is to reduce the physical working necessity in heavy work. This research is conducted to determine work and work environment based physical strains on employees of five companies that produce furniture in different cities in Turkey. Therefore, a checklist has been prepared that 239 individuals, who work in departments of massive processing, board processing, sanding, assembly, finishing and packaging, are asked to evaluate their working conditions and environment. The checklist consists of 60 questions related to operation by hand, physical energy consumption, musculoskeletal system usage, working tools and equipment, workstation and work facilitation. As a result of this research, it is concluded that working conditions and working environment conditions increase strain in individuals $(p<0.05)$ and reduce job satisfaction $(p<0.001)$. There is also the high correlation between working environment and job satisfaction $(r=-.436, p<0.001)$. It is expected that the results of this research will be useful for increasing working life quality of the employees and improving their health and work efficiency.

\section{Giriş}

Endüstriyel üretim ve diğer pek çok sektörde çalışmalar elle (manuel olarak) yapılmaktadır. Mobilya sektörü de emek yoğun ve işin genellikle elle yapıldı̆̆ı sektörlerden biridir. Sektördeki işletmelerin küçük ölçekli olması ve kayıt dışı istihdamın yoğunluğu nedeniyle ülkemizde bu konuda sağlıklı verilere ulaşılması pek olanaklı değildir. Çalışma ve Sosyal Güvenlik Bakanlığı'nın İşgücü Piyasası Araştırma Sonuçlarına göre (2008) 50 ve daha fazla kişi istihdam eden işletmelerdeki "ağaç ürünleri imalatı"nda çalışanların oranı \% 0.73 'dür. Mobilya imalatında sigortalı olarak çalışanların oranı ise \% 1.25 'dir (SGK, 2014). Bu sektör genellikle erkeklerin ve eğitim düzeyi düşük kadınların çalıştığı bir sektördür. Algılanan sağlık riskleri ve sağlık üzerinde çalışma koşullarının etkisi önemli ve dikkat edilmesi gereken bir konudur. Zira bu sektörde çalışanlar yüksek düzeyde fiziksel riske maruz kalmaktadır. Özellikle 50 yaş altındakilerde ve daha çok erkeklerde iş zorlanması bir sorundur (Eurofound, 2012).

Bu nedenle mobilya sektöründe insan-makine, insançevre ilişkileri değerlendirilirken vücut hareketlerinin detaylı ele alınması ve dinamik çalışmalar sırasında uygun olmayan vücut duruşlarının analiz edilmesi gerekir (Bullock, 1994). Zira ergonomi ilkeleri, işi ve koşulları insana uydurmak için çaba gösterir. Bu nedenle, kas-iskelet sistemi bozulmalarının kontrolünde ve fiziksel varyasyonun önemi üzerinde durulmakta, iş istasyonlarının doğru tasarımı ve uygun duruş teknikleri öğretilmeye çalışılmaktadır (Ahasan vd., 1996). İşle ilgili bozulmalar çok faktörlüdür. Bilinen risk faktörleri kişisel özellikler, çalışma duruşu, tekrarlı hareketler ve çalışma yeri / iş istasyonu tasarımıdır (Cheung vd., 2008). Pekçok çalışmanın sonuçlarına göre, sağlıksız duruştan kaynaklanan fiziksel yükün azaltılması, iș durumunu düzeltmede temel önlemler-den biri olarak görülmektedir. Posturel stresin miktarını belirlemek için vücut duruşunun eklemlere olan etkileri (Genaidy vd., 1994), duruş ve kazalar arasındaki ilişki, yorucu duruşların zararlı etkileri araștırılmıştır (Niskanen, 1985; Wickstrom vd., 1985).

Tekrarlı ve zorlayıcı çalışma koşulları ile ilişskili kasiskelet bozuklukları (WMSD) endüstrileşmiş ülkelerde en büyük sağlık sorunlardan birini teşkil etmektedir (Nunes ve Bush, 2012). Çoğu mobilya üretim işletmesinde üretilen ürünün doğası gereği (ağır, hantal ve zor) gerçekleştirilmesi zor, çok sayıda manuel çalışma (zımpara, sürtme, zımbalama ve püskürtme) gerektirir (Mirka, 2005). Bu nedenle kasiskelet hastalıkları sektörde en yaygın sağlık sorunudur, özellikle gelișmekte olan ülkelerde kasiskelet bozulmaları sakatlıkların, kazaların ve meslek hastalıklarının en önemli nedenidir. Yapılan araştırmalar mekanize ve otomatize edilmiş çalışmalara karşın mobilya sektöründe hala pek çok işin elle yapıldığını ortaya koymaktadır (David vd., 2008; Falaki vd., 2014). Bu sektörde kas-iskelet sistemi hastalıkları prevalansı yüksektir, bu da bireyin yaşam kalitesinini düşmesine, zaman ve emek kaybına, ürün maliyet artışına neden olmaktadır. Geleneksel mobilya üretiminin yoğun olduğu gelişmekte olan ülkelerde birey biyomekanik risk faktörleri ve kas-iskelet sistemi hastalıkları ile karşı karşıya kalır; biyomekanik, çevresel, zihinsel ve örgütsel faktörler ile cinsiyet, yaş, vücut kitle indeksi gibi parametrelerden etkilenir (Falaki vd., 2014:16). Çalışma yaşamında kas-iskelet sistemi rahatsızlıkları (KİSR); tendon, kas, sinir ve diğer yumuşak dokularda hasara neden olan eğilme, bükülme, gerilme, 
çömelme, kavrama, tutma, döndürme, sıkıştırma, uzanma ve taşıma gibi tekrarlayıcı fiziksel hareketler nedeniyle oluşmaktadır (Esen ve Fığlalı 2013; Labaj vd., 2016). KISR'nin gelişmesinde fiziksel ve psikososyal faktörlerin önemli rol oynadığı konusunda bilimsel çalışmalar bulunmaktadır (Devereux vd., 2004; Bugajska vd., 2013). Mobilya üretiminde fiziksel risk faktörleri tekrarlı hareketler, manuel malzeme taşıma, çalışma süresi, harcanan çaba, görsel talep, vibrasyonlu araç kullanma ve sürme gibi vücudun farklı bölümlerinin (boyun, sırt, omuz, kol, bilek ve el gibi) uygun olmayan durumlarla karşı karşıya kalması sonucu oluşur. Psikososyal risk faktörleri ise iş temposu ve stresinden kaynaklanır (David vd., 2008). Çalışma koşulları ile KISR insidansı arasında güçlü bir korelasyon vardır. KİSR'ye neden olan bu risk faktörleri uygun olmayan vücut pozisyonu, tekrarlı çalışma, mola vermeden uzun süre çalışma, aşırı güç uygulama, statik çalışma, iş hızı ve çalışma ortamı koşulları şeklinde sınıflandırılabilir. Ancak bu risk faktörlerinden hiçbiri tek başına fiziksel zorlanmalara ve KISR'e neden olmamaktadır. Fiziksel zorlanma ve kas iskelet sistemi rahatsızlıkları genellikle bu faktörlerin kombinasyonu ve etkileşimi sonucu meydana gelmektedir (David vd., 2008; Nunes ve Bush 2012:3).

Karasek (1979)'e göre iş üzerindeki denetimlerin sınırlı olması nedeniyle ișçilerde çalıșmaya bağlı fiziksel risklerden yakınma yüksektir. Mobilya sektörü de fiziksel riske en fazla maruz kalınan sektörlerden biridir. Bu sektörde en yaygın fiziksel risk postür ve hareketle ilgilidir. Bu olumsuzlukların giderilmesinde ergonomik uygulamalar; bilek, omuz ve sırtla ilgili zorlanma, ağrı ve acıları, gürültüye bağlı işitme kaybını ve işle ilgili astım gibi sağlık sorunlarının sıklığını ve ortaya çıkma olasılığını azaltabilir. Ekipman kontrol ve düzeni, ulaşım, ekipman-birey uyumu gerçekleştirilerek ergonomik riskler en aza indirilebilir (HSE, 2013). Daha iyi sonuç ve artan verimlilik, daha uygun çalışma ortamının bir sonucu olarak kabul edilir. Fiziksel çalışma ortamının iyileştirilmesi çalışanın verimlilik ve konforunu artırır (Hameed ve Amjad, 2009), böylece birey uzun süre yorgunluk ve zorlanma olmadan çalışabilir.

İşletmelerde çok az / çok fazla iş talebi, çalışanların iş organizasyonunda yeterli bilgi sahibi olmaması, çalışma hızına uygun olmayan kötü tasarlanmış makineler, yüksek verimlilik ve kalite isteği gibi sorunlar çalışanlarda çeşitli sağlık sorunlarına neden olabilir. Manuel çalışmalarda da; birey üzerinde aşırı yüklenme ve/veya fazla iş yükü, yükün omuz üzerine kaldırılması, çok sık tekrarlı hareket, eğilme-kıvrılma, yükün düzgün kavranmaması, zaman baskısı ve yeterli dinlenme arası verilmemesi çeşitli sorunları beraberinde getirir (HSE, 2013). Manuel malzeme taşıma (ağır yük kaldırma, indirme, taşıma, çekme ve itme gibi), zorlu duruşlar ve zayıf çalışma koşulları gibi fiziksel aktiviteler çok yaygındır (Nejad vd., 2013). Mobilya üretimi KİSR'nin en yoğun olduğu, bel, sırt ve omuz sorunlarının en çok yaşandığı sektörlerden biridir. Özellikle depolama, üretim ve dağıtım aşamalarında bedensel zorlanma ve sakatlanmalar daha fazla olmaktadır. Bu bozukluklara neden olan sayısız risk faktörü vardır. $\mathrm{Bu}$ risk faktörleri biyomekanik, psikososyal ve bireysel olarak sınıflandırılmaktadır. Çalışma koşulları ve çalışma biçiminin neden olduğu biyomekanik risk faktörleri mobilya sektöründe çok sık gerçekleşen eğilme, bükülme, kaldırma, itmeçekme, ağır fiziksel iş, tekrarlı iş, postür-duruş ve vibrasyondan kaynaklanmaktadır. Bu riski azaltmada en önemli yaklaşım ağır çalışmalarda fiziksel iş ihtiyacını azaltmaktır. Bireye bağlı olarak iş stresi değişmekte, psikososyal stres omurga yüklenmesi ve bel bozukluğu sıklığını artırmaktadır. Bedensel zorlanmayı ve riski artıran diğer faktörler yaş, cinsiyet, sigara içme, iş deneyimi gibi bireysel olanlardır. $\mathrm{Bu}$ yaklaşımların her biri yapılan iş, çalışma yeri çevresi ve bedensel zorlanmalar arasındaki karmașık ilișkiler hakkında veriler ortaya koymaktadır (Nejad vd., 2013; Ferguson vd., 2012; Davis ve Heaney, 2000; Van der Molen vd., 2005). Biyomekanik tehlikeler, genetik yatkınlık, morfolojik dezavantajlar ve psikososyal eğilim işle ilgili kasiskelet sorunlarını ve zorlanmaları artırır, ancak biyomekanik ve psikososyal faktörler kontrol edilerek olumsuzluklar ortadan kaldırılabilir (Vieira ve Kumar, 2004). İș yerinde birey üzerinde baskı ve zorlanma olușturan ergonomik risk faktörlerinin kontrol altına alınması kas-iskelet sistemi rahatsızlıklarını ve işle ilgili olumsuz maruziyeti ortadan kaldırır. Maruziyet değerlendirmesi sonucunda işle ilgili zorlanmaların çoğunlukla sırt, omuzlar, boyun ve üst ekstremitlerde yoğunlaștığı (David vd., 2008); hatta statik yüklenmenin kasiskelet sistemi rahatsızlıklarını artırdığı, düşük yoğunlukta bile omuz ve boyun bölgesinde sorunlara neden olduğu anlaşılmıştır (Commissaris vd., 2006). Tüm bu olumsuzluklar çalışma ortamı koşulları insan temeli üzerinden yeniden organize edilerek zorlanmalar ve rahatsızlıklar ortadan kaldırılabilir.

\section{Materyal ve Yöntem}

Bu çalışma ülkemizde farklı illerde (Denizli, İstanbul, Ankara ve Osmaniye) mobilya üretimi yapan büyük (2) ve orta ölçekli (2) dört işletmede çalışanların iş memnuniyeti ve zorlanmalarını belirlemek amacıyla yapılmıştır.

Araştırmada önce çevresel / örgütsel risk faktörleri ve ortam koșulları değerlendirilmiștir. Çevresel / örgütsel risk faktörleri "evet" ve "hayır" olarak 0-1 puanla, ortam koşulları ise "çok fazla" ve "çok az" arasında değişen 5'li Likert tipi cümlelere verilen puanlarla değerlendirilmiştir.

Bireyin iş ve iş ortamına ilişkin değerlendirmesini belirlemek amacıyla bir kontrol listesi hazırlanmış; 
masifleme, levha işleme, zımparalama, montaj, vernik-boya ve paketleme birimlerinde çalışan 239 bireyin çalışma koşullarını ve ortamı değerlendirmesi istenmiştir. Değerlendirme elle çalışma (1), fiziksel enerji tüketimi (2), kas-iskelet sistemi kullanımı (3), işte kullanılan araç ve gereçler (4), çalışma istasyonu (5) ve iş kolaylaştırmaya (6) ilişkin 60 soruyu içermektedir (Anon, 2011; Nejad vd., 2013; Dababneh vd., 2004). (Tablo 1).

Tablo 1. İș ve iș ortamına ilișkin kontrol listesi soru dağılımı

\begin{tabular}{llc}
\hline Sıra & Kontrol listesi & Soru sayısı \\
\hline 1 & Elle çalıșma & 8 \\
2 & Fiziksel enerji tüketimi & 12 \\
3 & Kas-iskelet sistemi kullanımı & 8 \\
4 & Araç ve gereçler & 7 \\
5 & Çalışma istasyonu & 16 \\
6 & İș kolaylaştırma & 9 \\
\hline Toplam & & 60 \\
\hline
\end{tabular}

Bu sorulara "evet" ve "hayır" olarak yanıtlar verilmiș, cümlenin olumlu-olumsuz olma durumuna göre 0-1 puanla değerlendirilmiştir. Sorulara verilen yanıtların toplam puanları 1-15 arasında olduğunda çalışma koşulları "kötü", 16-30 arasında "orta", 31-45 arasında "iyi", 46 ve üzerinde olduğunda "çok iyi" olarak nitelenmiştir. İş ortamına ilişkin değerlendirmede yanıt "evet" olduğunda bireyin bedeninin hangi bölümünde (boyun, omuzlar ve sırtın üst bölümü-A, dirsek, önkol ve eller-B, ayaklarC, diz ve kalça-D ve bel-E) zorlanma yaşadığını işaretlemesi istenmiştir (Şekil 1).

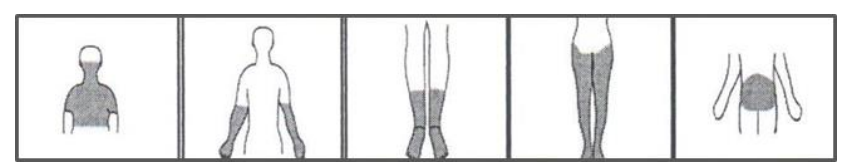

Şekil 1. Bedende zorlanma olan bölümler

Çalışanların işle ilgili genel memnuniyetlerini 1-10 arasında puanlamaları istenmiștir. Değerlendirme puanı 1-4 arasında olanların düşük, 5-7 puan arasında olanların orta, 8 ve üzerinde puana sahip olanların yüksek memnuniyet düzeyine sahip oldukları varsayılmıştır.

Bireysel özellikler (yaş, iş deneyimi, sigara kullanımı, çalışılan birim, bedensel zorlanma durumu), bireyin yaptığı iş ve ortam koşulları ile elle çalışma, fiziksel enerji tüketimi, kas-iskelet sistemi kullanımı, işte kullanılan araç ve gereçler, çalışma istasyonu ve iş kolaylaştırma konusunda fiziksel zorlanma ve rahatsızlıklar arasındaki ilişki araştırılmıştır. Araștırmada ayrıca fiziksel rahatsızlık ile ortam puanı arasındaki ilişki $\mathrm{t}$ testi ve korelasyon analizi ile araştırılmıştır. Memnuniyet düzeyleri ile çalışma zorluğu arasındaki ilişki ise korelasyon analizi ve varyans analizi (Oneway ANOVA) ile belirlenmiștir. Testler 0.05 anlamlılık düzeyinde yapılmıștır.
Araştırma sonuçlarının bireyin çalışma yaşamı kalitesini artırmada, sağlı ve iş verimini iyileștirmede yararlı olması beklenmektedir.

\section{Bulgular ve Tartışma}

\section{1.Çalışanlara İlişkin Bilgiler}

İşletmelerde çalışan personelin yaşları 17-60

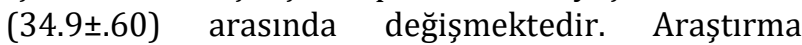
kapsamına alınan 4 işletmenin üretim biriminde yalnızca iki kadın çalışan bulunmaktadır. Çalışanların \% 46.9'u sigara kullanmaktadır. İş yaparken çalışanların \% 85.8'i yalnız sağ elini, \% 6.7'si ise yalnız sol elini kullanmaktadır. Diğer çalışanlar $(\%$ 7.5) ise her iki elini aynı performansla kullanmaktadır. Mobilya sektöründe çalışma süresi 142 yıl arasında değişmekte olup, \% 23.1'i 20 yll ve daha uzun süredir sektörde çalışmaktadır. Aynı iş yerinde 10 yıl ve daha uzun süredir çalışanlar $\% 16.5$ oranındadır. İșçilerin \% 30.7'si panel ișleme, \% 20.6'sı masif işleme, \% 19.7'si montaj, \% 16.0'sı zımparalama, \% 6.7'si paketleme ve \% 3.8'i vernikboya uygulama birimlerinde çalışmaktadır. Geriye kalan \% 2.5'i ise kalite kontrol ve depo birimlerinde çalıșmaktadır. Bu birimlerde çalıșanlar daha çok makine operatörü (\% 29.8), montaj (\% 13.4) ve zımparalama (\% 12.1) işlerini gerçekleştirmektedirler. Diğer yaygın yapılan işler arasında paketleme (\% 7.5), masif işleme, vernik-boya, kenar bantlama, kaplama pres ve kalite kontrol işlemleri yer almaktadır. İşletmelerde en az yapılan işler arasında kusur arama, soğuk laminasyon pres, kertikkanal açma, kalibre zımparalama makinesi kullanma, kaplama kesim, ebatlama, çerçeve pres operatörü, silim, panel kesim, delik delme, sevkiyat, kutu mobilya imalatı vb. yer almaktadır.

Son beş yıl içinde çalışanların \% 16.7'si iş yaparken kazaya uğramıştır. Gerçekleşen kazalar içinde makinede parmak kesilmesi (\% 40.0), eli makineye sıkıștırma (\% 31.4) ve parça firlaması ile yaralanma (\%14.3) ilk üç sırayı almaktadır. Bunun yanında kolunu makineye sıkıştırma, makineden düşme, kafayı çarpma, ele parça düşmesi gibi kazalara da rastlanmaktadır.

Çalışanların \% 60.3'ü de işle ilgili bedensel zorlanma yaşamaktadır.

- Zorlanma yașayanlar birinci derecede zorlanma nedeni olarak "malzemeler ağır, kaldırma, taşıma ve yüklemede fiziksel olarak zorlanıyorum (\% 50.0)", "iş çok fazla eğilme (öne, yana, geriye), kalkma, çömelme ve uzanmayı gerektiriyor (\% 21.1)" ve "iş sürekli ayakta çalışmayı gerektiriyor (\%20.4)" yanıtını vermişlerdir.

- Zorlanmanın ikinci nedeni olarak da yine "iş sürekli ayakta çalışmayı gerektiriyor (\%33.9)" ve "iş çok fazla eğilme (öne, yana, geriye), kalkma, 
çömelme ve uzanmayı gerektiriyor ( $\%$ 33.1)” yanıtı verilmiştir.

- Üçüncü sırada ise "iş sürekli ayakta çalışmayı gerektiriyor (\%31.1)", "tekrarlı hareketler çok fazla (\% 21.7)" ve "çalışma hızı çok yüksek (\% 13.2)" şeklindedir.

Bu sonuç mobilya sektöründe bireylerin zorlandı̆̆ını, işin fiziksel olarak ağır ve ayakta çalışmayı gerektirdiğini, uygun olmayan çok fazla postür olduğunu, çalışma hızının yüksek ve tekrarlı hareketlerin fazla olduğunu ortaya koymaktadır. Bedensel zorlanma ile iș memnuniyeti arasındaki ilişki korelasyon analizi ile araştırılmış, bedensel zorlanma arttıkça iş memnuniyetsizliğinin arttığl $(\mathrm{r}=.263, \mathrm{p}<0.001)$ belirlenmiștir.

\subsection{Risk Faktörleri}

Araştırma kapsamına alınan mobilya çalışanlarına risk faktörleri sorulduğunda çalıșanların \% 60.5'i "zorlanma arttığında mola ve ara verme ihtimali olmadığını”, \% 65.2'si "iş hızı ya da görev çeşidini ve sıralamayı seçme olanağı” olmadığını, \% 48.9'u "işin zaman sinırlaması ya da psikolojik stres altında yapıldığını" ve \% 56.8'i de "ișin beklenmedik ve alışılmamış durumlara sahip olduğunu" ifade etmiştir.

\subsection{Ortamın Fiziksel Koşulları}

Çalışanların kendi çalışma ortamlarının fiziksel koşullarını değerlendirmeleri istendiğinde \% 65'i ortam sıcaklığının, \% 56.9'u gürültünün yüksek, yarıya yakını nemin normal (\% 44.1) olduğunu, \% 39.0'u toz düzeyinin, \% 19.8'i kimyasalların, \% 19.2'si hava akımının, \% 15.5'i vibrasyonun ve \% 20.4'ü ise aydınlatmanın fazla olduğunu belirtmiștir. Yapılan LSD (Least Significant Difference Test) analizinde zımparalama işlemi ile masif işleme, panel işleme ve paketleme birimleri arasında ortam koşulları bakımından anlamlı farklılık olduğu $(\mathrm{p}<0.05)$ belirlenmiştir. Zımparala işleminde özellikle toz nedeniyle memnuniyetsizlik puanı en yüksek iken, paketleme bölümündekilerde memnuniyetsizlik en düşük bulunmuştur $(\mathrm{p}<0.05)$. Gürültü düzeyi normalin üzerinde (90 dB A), aydınlatma yetersizdir. Bielski vd. (1976) tarafından yapılan çalışmada da en fazla stresin yatay bant zımpara ve testereden, en az stresin hidrolik sıcak plakalı pres ve zincirli kenar yapıștırma makinesinden kaynaklandığı belirlenmiştir. Bu sonuç araştırma sonuçlarındaki memnuniyetsizliğin nedenini de açıklamaktadır.

\subsection{Calışma Ortamının Değerlendirilmesi}

Çalışanların iş ortamını değerlendirmeleri masifleme, levha işleme, zımparalama, montaj, vernik-boya ve paketleme birimleri için hazırlanan kontrol listelerine verdikleri yanıtlara göre belirlenmiștir. Araștırma kapsamına alınan işletmelerde çalışan bireylerin iş ve iş ortamına ilişkin değerlendirmeleri elle çalışma, fiziksel enerji tüketimi, kas-iskelet sistemi kullanımı, işte kullanılan araç ve gereçler, çalıșma istasyonu ve iş kolaylaştırma olmak üzere altı başlıkta ele alınmıştır. Buna göre bireyin iş ve iş ortamına ilişkin değerlendirmesi Tablo 2'de yer almaktadır.

Tablo 2. Bireyin iş ve iş ortamına ilişkin değerlendirmesi: Elle çalışma (n=239)

\begin{tabular}{|c|c|c|c|c|c|c|c|c|}
\hline & & \multirow[t]{2}{*}{ İş ve iş ortamına ilişkin kontrol listesi } & \multicolumn{2}{|c|}{ Evet } & \multicolumn{2}{|c|}{ Hayır } & \multirow{2}{*}{$\mathbf{F}$} & \multirow{2}{*}{$\mathbf{p}$} \\
\hline & & & Sayı & $\%$ & Sayı & $\%$ & & \\
\hline \multirow{9}{*}{ 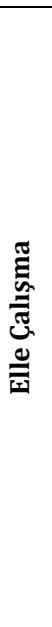 } & EÇ1 & $\begin{array}{l}\text { Yaptı̆̆ınız iş araç, yük ya da parçaların kaldırılmasını } \\
\text { gerektiriyor mu? }\end{array}$ & 193 & 87.3 & 28 & 12.7 & 7.581 & $.001^{* *}$ \\
\hline & $\mathrm{EÇ2}$ & $\begin{array}{l}\text { Yaptı̆̆ınız iş araç, yük ve parçaların indirilmesini } \\
\text { gerektiriyor mu? }\end{array}$ & 164 & 74.9 & 55 & 25.1 & 3.329 & $.038^{*}$ \\
\hline & EÇ3 & $\begin{array}{l}\text { Yaptığınız iş başın üzerinde araç, gereç ve parçalara } \\
\text { uzanarak çalışmayı gerektiriyor mu? }\end{array}$ & 115 & 52.5 & 104 & 47.5 & 1.700 & .185 \\
\hline & EÇ4 & $\begin{array}{l}\text { Yaptığınız iş araç, yük ve parçaları tutmak ve kullanmak } \\
\text { için belden bükülme (yana eğilme) gerektiriyor mu? }\end{array}$ & 176 & 79.6 & 45 & 20.4 & 2.858 & .060 \\
\hline & EÇ5 & $\begin{array}{l}\text { Yaptığınız iş araç, yük ve parçaları tutmak ve kullanmak } \\
\text { için belden kıvrılma, bükülme (öne eğilme) gerektiriyor } \\
\text { mu? }\end{array}$ & 195 & 84.1 & 37 & 15.9 & 1.676 & .190 \\
\hline & EÇ6 & $\begin{array}{l}\text { Yük kaldırma ve taşıma sırasında kavrama zorlukları } \\
\text { yaşanıyor mu? }\end{array}$ & 131 & 57.2 & 98 & 42.8 & 5.997 & $.003^{* *}$ \\
\hline & EÇ7 & $\begin{array}{l}\text { Surt ve bel incinmesi riski oluşturabilecek yüklerin } \\
\text { itilmesi, çekilmesi, kaldırılması ve indirilmesini } \\
\text { sağlayacak uygun mekanik taşıma araçları var mı? }\end{array}$ & 162 & 70.7 & 67 & 29.3 & 1.994 & .139 \\
\hline & EÇ8 & $\begin{array}{l}\text { Yüklerin elle taşınmasından kaynaklanabilecek kas } \\
\text { iskelet sistemi hastalıkları konusunda bilginiz var mı? }\end{array}$ & 124 & 61.1 & 79 & 38.9 & .808 & .447 \\
\hline & Toplam & 4.786 \pm .118 (8 puan üzerinden) & & & & & 4.211 & $.016^{*}$ \\
\hline
\end{tabular}

Tablo 2'ye göre elle çalıșmada bireyin en çok zorlandığı işler arasında "Yapılan işin araç, yük ya da parçaların kaldırılmasını gerektirmesi" ve "Yapılan işin araç, yük ve parçaları tutmak ve kullanmak için belden kıvrllma, bükülme (öne eğilme) gerektirmesi" yer almaktadır. Bunu "yapılan işin araç, yük ve parçaların indirilmesini gerektirmesi (\% 74.9)" ve "yapılan işin araç, yük ve parçaları tutmak ve kullanmak için belden bükülme (yana eğilme) gerektirmesi (\% 73.6)" izlemektedir.

Fazla zorlanmaya neden olduğu halde ișletmelerde en az yapılan işler arasında "baş üzerinde araç, gereç ve parçalara uzanarak çalışma (\% 47.5)" ve "yük kaldırma ve taşıma sırasında kavrama zorluklarının yașanması (\% 42.8)" almaktadır. 
İșin elle yapılmasında bireyin fiziksel zorlanma durumu ile iş memnuniyeti arasındaki ilişki korelasyon analizi ile araştırılmış, elle çalışma konusunda olumsuz değerlendirme arttıkça bireyin işle ilgili memnuniyet puanının düştüğü belirlenmiştir ( $\mathrm{r}=-.225$, $\mathrm{p}<0.001)$.

İşin elle yapılmasına ilişkin olarak her bir maddenin memnuniyet düzeyine göre değerlendirmesi OneWay ANOVA ile yapılmıştır. Varyans analizi sonucunda 1,2 ve 6 . maddelerde fark önemli bulunmuş, olumsuz değerlendirme arttıkça memnuniyet düzeyi düşmüştür. $\mathrm{Bu}$ durum çalışanların özellikle yük kaldırma, taşıma ve yükü kavramada zorlanmaları ile ilgilidir. Buna karşılık eğilme ve uzanmadan kaynaklanan zorluklar konusunda çalışanlar arasında fark olmadığı ( $p>0.05)$ belirlenmiştir. Bu sonuç yük kaldırma, indirme ve taşımanın mekanik araçlarla yapılmasından kaynaklanmaktadır. İnsan gücü kullanımı azaldıkça fiziksel zorlanma da azalmakta, buna karşılık memnuniyet artmaktadır.

İşin elle yapılmasına ilişkin değerlendirmeye yönelik toplam puan ile iş memnuniyeti arasındaki ilişki anlamlıdır $(\mathrm{F}=4.211, \mathrm{p}<0.05)$. Bu sonuç işin elle yapılmasına ilișkin zorlanma arttıkça memnuniyetin azaldığını göstermektedir.

Fiziksel enerji tüketimine göre değerlendirme sonuçları Tablo 3'de yer almaktadır.

Tablo 3. Bireyin iș ve iș ortamına ilișkin değerlendirmesi: Fiziksel Enerji Tüketimi (n=239)

\begin{tabular}{|c|c|c|c|c|c|c|c|c|}
\hline & & \multirow{2}{*}{ Fiziksel Enerji Tüketimine ilişkin kontrol listesi } & \multicolumn{2}{|c|}{ Evet } & \multicolumn{2}{|c|}{ Hayır } & \multirow{2}{*}{$\mathbf{F}$} & \multirow[b]{2}{*}{$\mathbf{p}$} \\
\hline & & & Sayı & $\%$ & Sayı & $\%$ & & \\
\hline \multirow{13}{*}{ 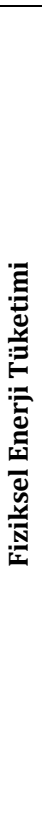 } & FE1 & $\begin{array}{l}\text { Çalışmada 4,5-5 kg'dan daha ağır araç ya da parça var } \\
\text { mı? }\end{array}$ & 202 & 84.5 & 37 & 15.5 & 6,030 & $.003^{* *}$ \\
\hline & FE2 & $\begin{array}{l}\text { Yaptığınız iş kalas ve ağaç parçaları vb. gibi elle } \\
\text { taşınamayacak kadar ağır yükleri kaldırmayı } \\
\text { gerektiriyor mu? }\end{array}$ & 113 & 47.3 & 126 & 52.7 & 14.395 & $.000^{* *}$ \\
\hline & FE3 & $\begin{array}{l}\text { Yaptığınız iş uzun süre aynı pozisyonda kalmayı } \\
\text { gerektiriyor mu? }\end{array}$ & 141 & 59.0 & 98 & 41.0 & 2.020 & .135 \\
\hline & FE4 & $\begin{array}{l}\text { Yaptığınız iş fiziksel anlamda zorlayıcı çalışmaları (ağır } \\
\text { yük kaldırma dahil) gerektiriyor mu? }\end{array}$ & 167 & 69.9 & 72 & 30.1 & 7.377 & $.001^{* *}$ \\
\hline & FE5 & $\begin{array}{l}\text { Yaptığınız iş } 50 \mathrm{~cm} \text { 'den daha ileriye uzanmayı } \\
\text { gerektiriyor mu? }\end{array}$ & 135 & 56.5 & 104 & 43.5 & 6.988 & $.001^{* *}$ \\
\hline & FE6 & $\begin{array}{l}\text { Yaptığınız iş bükülme, eğilme, kamburlaşma, çömelmeyi } \\
\text { gerektiriyor mu? }\end{array}$ & 198 & 82.8 & 41 & 17.2 & 5.448 & $.005^{* *}$ \\
\hline & FE7 & $\begin{array}{l}\text { Yaptığınız iş yükle yürümeyi ya da yük taşımayı } \\
\text { gerektiriyor mu? }\end{array}$ & 162 & 67.8 & 77 & 32.2 & 6.562 & $.002^{* *}$ \\
\hline & FE8 & $\begin{array}{l}\text { Yaptığınız iş yükle merdiven ya da basamak çıkmayı / } \\
\text { inmeyi gerektiriyor mu? }\end{array}$ & 50 & 20.9 & 189 & 79.1 & 6.667 & $.002^{* *}$ \\
\hline & FE9 & Yaptığınız iș itme ve çekme biçiminde mi? & 144 & 60.3 & 95 & 39.7 & 3.338 & $.037^{*}$ \\
\hline & FE10 & Yaptığınız iş yukarıya uzanma biçiminde mi? & 77 & 32.2 & 162 & 67.8 & 0.777 & .461 \\
\hline & FE11 & $\begin{array}{l}\text { Yukarıdaki iş etkinliklerinden herhangi biri dakikada } 5 \\
\text { ya da daha fazla tam iş devrini (tekrarı) gerektiriyor } \\
\text { mu? }\end{array}$ & 132 & 55.2 & 107 & 44.8 & 3.740 & $.025^{*}$ \\
\hline & FE12 & $\begin{array}{l}\text { Dinlenme araları ve iş araları yaptığınız iş için yeterli } \\
\text { mi? }\end{array}$ & 118 & 49.4 & 121 & 50.6 & 3.096 & $.047^{*}$ \\
\hline & Toplam & $6.945 \pm .164$ (12 puan üzerinden) & & & & & 15.292 & $.000^{* *}$ \\
\hline
\end{tabular}

Tablo 3'e göre "çalışmada 4,5-5 kg'dan daha ağır araç ya da parça var olması (\% 84.5)" ve "yapılan işin bükülme, eğilme, kamburlaşma, çömelmeyi gerektirmesi (\% 82.8)" en önemli olumsuzluklar arasındadır. Bunu "yapılan işin fiziksel olarak zorlayıcı çalışmaları (ă̆ır yük kaldırma dahil) gerektirmesi (\% 69.9)" ve "işin yükle yürümeyi ya da yük taşımayı gerektirmesi (\% 67.8)" izlemektedir.

"Yapılan işin yükle merdiven ya da basamak çıkmayı / inmeyi" ve "yukarlya uzanmayı gerektirmemesi" olumlu özellikler arasında yer almaktadır. Çalışanların yaklaşık yarısı da "işin kalas ve ăgaç parçaları vb. gibi elle taşınamayacak kadar ağır yükleri kaldırmayı gerektirdiğini" ve "dinlenme araları ve iş aralarının yapılan iş için yeterli olmadığını" belirtmişlerdir.
Çalışmada fiziksel enerji tüketimine dönük zorlanma ile iş memnuniyeti ilişkisi korelasyon analizi ile araştırılmış, fiziksel enerji tüketimi konusunda olumsuz değerlendirme arttıkça bireyin işle ilgili memnuniyet puanının düştügü belirlenmiştir ( $\mathrm{r}=$ .357, p<0.001). Fiziksel enerji tüketimine ilişkin olarak her bir maddenin memnuniyet düzeyine göre de değerlendirmesi One-Way ANOVA ile yapılmıştır. Varyans analizi sonucunda 3 ve 10 . maddeler dışındaki 10 maddede fiziksel enerji tüketimi ile iş memnuniyeti arasındaki ilişki önemli bulunmuştur. Fiziksel yük arttıkça iş memnuniyetinin azaldığı görülmektedir. Bireylerin iş yükünün fazla ve zorlayıcı olduğu, ağır parçalar kaldırdıkları, işin yürüme, eğilme, bükülme ve uzanma gerektirdiği $(\mathrm{p}<0.05)$ anlaşılmaktadır. Bireylerin büyük çoğunluğu uzun süre aynı pozisyonda çalışmakta ve yaptıkları iş yukarıya doğru uzanmayı gerektirmemektedir. Bu bireyler arasında iş memnuniyeti açısından fark 
bulunmamaktadır (p>0.05). Buna karşılık fiziksel enerji tüketimine ilişkin genel değerlendirme puanı ile iş memnuniyeti arasındaki ilişki anlamlıdır $(\mathrm{F}=15.292, \mathrm{p}<0.001)$. Bu sonuç fiziksel enerji tüketimi arttıkça memnuniyetin azaldığını göstermektedir. Çalıșma sırasında kas-iskelet sistemi kullanımı incelendiğinde sonuçlar Tablo 4'de yer almaktadır.

Tablo 4. Bireyin iş ve iş ortamına ilişkin değerlendirmesi: Kas-İskelet Sistemi Kullanımı (n=239)

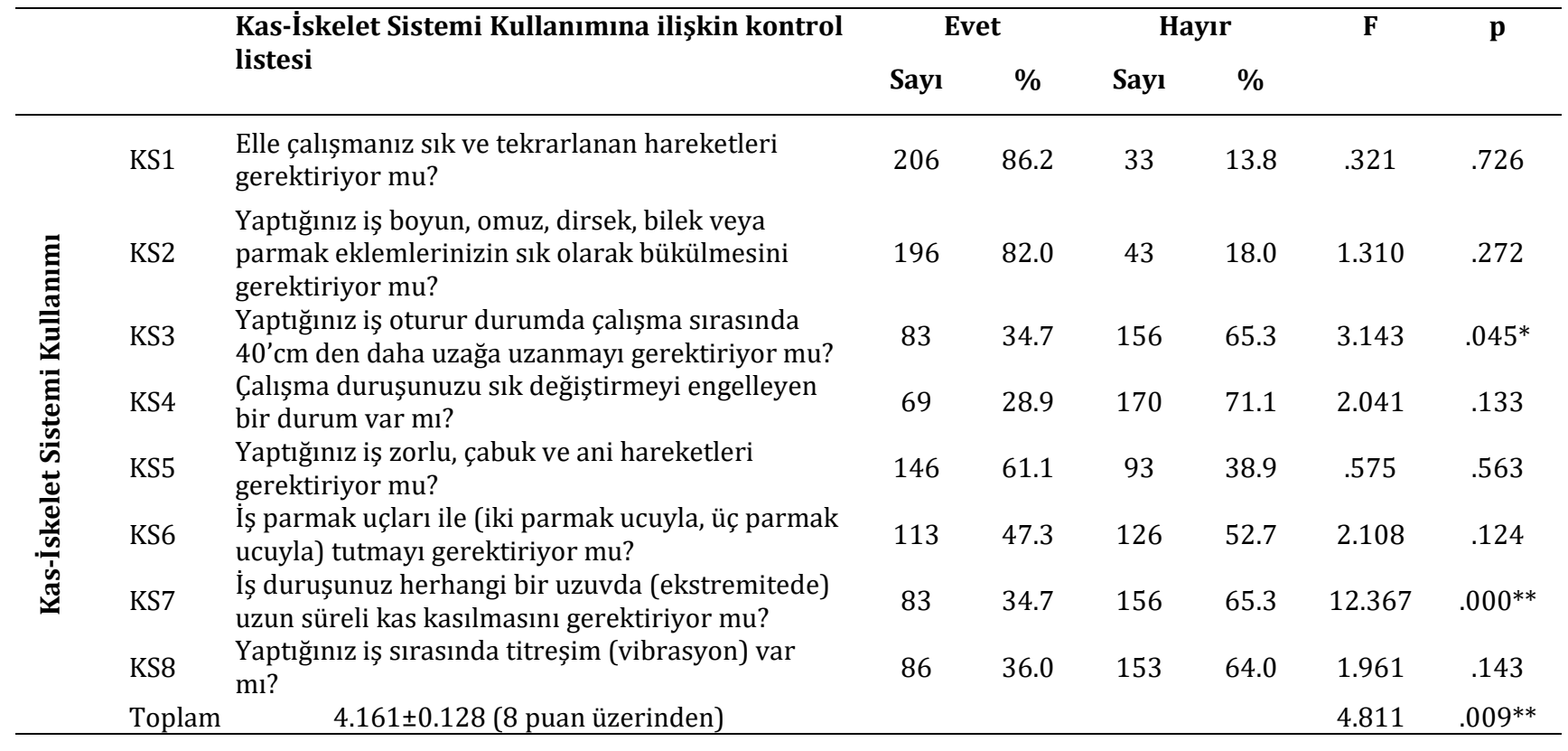
$* \mathrm{p}<0.05 * * \mathrm{p}<0.01$

Tablo 4'e göre "elle çalışmanın sık ve tekrarlanan hareketleri gerektirmesi (\% 86.2)" ve "işin boyun, omuz, dirsek, bilek veya parmak eklemlerinin sık olarak bükülmesini gerektirmesi (\% 82.0)" önemli olumsuzluklar arasında yer almaktadır. Bunu "yapılan işin zorlu, çabuk ve ani hareketleri gerektirmesi (\% 61.1)" izlemektedir.

"Çalışma duruşunun sık değiştirilmesine engel bir durum olmaması (\% 71.1)", "yapılan işin oturur durumda çalışma sırasında $40^{\prime} \mathrm{cm}$ den daha uzağa uzanmayı gerektirmemesi (\% 65.3)", "çalışma duruşunun herhangi bir uzuvda (ekstremitede) uzun süreli kas kasılmasını gerektirmemesi (\% 65.3)" ve "yapılan iş sirasında titreşimin (vibrasyon) olmaması (\% 64.0)" olumlu özellikler arasında yer almaktadır.

Kas-iskelet sistemi kullanımının fiziksel zorlanmaya etkisinin iş memnuniyeti üzerindeki etkisi arasındaki korelasyona bakıldığında, kas-iskelet sistemi kullanımı konusunda olumsuz değerlendirme arttıkça bireyin işle ilgili memnuniyet puanının düştüğü belirlenmiştir $(\mathrm{r}=-.214, \mathrm{p}<0.002)$.

Kas-iskelet sistemi kullanımında zorlanma konusunda her bir maddenin memnuniyet düzeyine göre değerlendirmesi de yapılmıştır. Varyans analizi sonucunda 3 ve 7. maddeler dışındaki 6 maddede kas-iskelet sistemi kullanımında zorlanma ile iş memnuniyeti arasındaki ilişki önemsiz ( $p>0.05)$ bulunmuştur. Kas-iskelet sisteminde zorlanma arttıkça iş memnuniyetinin azaldı̆̆ görülmektedir. Bireyin oturur durumda çalışırken $40^{\prime} \mathrm{cm}$ den daha uzağa uzandığı $(\mathrm{F}=3.143, \mathrm{p}<0.05)$ ve iş duruşunun herhangi bir uzuvda (ekstremitede) uzun süreli kas kasılmaya neden olduğu $(\mathrm{F}=12.367, \quad \mathrm{p}<0.01)$ anlaşılmaktadır. Kas-iskelet sistemi kullanımında zorlanmaya ilişkin genel değerlendirme puanı ile iş memnuniyeti arasında da anlamlı bir ilişki bulunmuştur $(\mathrm{F}=4.811, \mathrm{p}<0.009)$. Bu sonuç kasiskelet sisteminde zorlanma arttıkça memnuniyetin azaldığını göstermektedir.

Çalışma sırasında araç-gereçlerden kaynaklanan olumsuzluklar olup olmadığı incelendiğinde sonuçlar Tablo 5'de yer almaktadır.

Tablo 5'e göre belirgin olumsuzluklar arasında "alet/araç ăğırlığı 4-5 kg'dan fazla olması (\% 32.6)" ve "alet/aracın aşırı titreșim yapması (vibrasyonun yüksek olması) (\% 28.0)" yer almaktadır.

"Araca / makineye ulaşmanın zor olmaması (\% 90.4)", "kullanıcıya aşırı geri tepme etkisi yapmaması (\% 87.4)" ve "alet saplarının istenilen özelliklerde olması (\% 85.8)" istenilen özellikler arasındadır. Özellikle aletlerin kullanımının kolay, el ve bileğe baskı yapmayan, bükülme gerektirmeyen özelliklerde olması bireyin zorlanmasını azaltacağı gibi iş veriminin artmasını da sağlayacaktır. $\mathrm{Bu}$ durum mobilya işletmelerinde kullanılan araç-gereçlerin bireyin fazla zorlanmasını gerektirmeyen ürünlerden seçildiğini göstermektedir. 
Tablo 5. Bireyin iş ve iş ortamına ilişkin değerlendirmesi: Araç ve Gereçler $(n=239)$

\begin{tabular}{|c|c|c|c|c|c|c|c|c|}
\hline & & \multirow[t]{2}{*}{ Araç ve Gereçlere ilişkin kontrol listesi } & \multicolumn{2}{|c|}{ Evet } & \multicolumn{2}{|c|}{ Hayır } & \multirow[t]{2}{*}{$\mathbf{F}$} & \multirow[t]{2}{*}{$\mathbf{p}$} \\
\hline & & & Sayı & $\%$ & Sayı & $\%$ & & \\
\hline \multirow{8}{*}{ 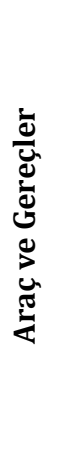 } & AG1 & Alet sapları çok küçük ya da çok büyük mü? & 34 & 14.2 & 205 & 85.8 & 1.886 & .154 \\
\hline & AG2 & $\begin{array}{l}\text { Kullanırken aletin sapı bileğinizin bükülmesine yol } \\
\text { açıyor mu? }\end{array}$ & 51 & 21.3 & 188 & 78.7 & 2.744 & .067 \\
\hline & AG3 & Araca / makineye ulașmak zor mu? & 23 & 9.6 & 216 & 90.4 & 1.133 & .324 \\
\hline & AG4 & Alet/araç ağırlığı 4-5 kg'dan fazla mı? & 78 & 32.6 & 161 & 67.4 & 3.469 & $.033^{*}$ \\
\hline & AG5 & $\begin{array}{l}\text { Alet/araç aşırı titreșim yapıyor mu? (vibrasyon } \\
\text { yüksek mi?) }\end{array}$ & 67 & 28.0 & 172 & 72.0 & 2.007 & .137 \\
\hline & AG6 & $\begin{array}{l}\text { Alet/araç kullanıcıya aşırı geri tepme etkisi } \\
\text { yapıyor mu? }\end{array}$ & 30 & 12.6 & 209 & 87.4 & 5.414 & $.005^{* *}$ \\
\hline & AG7 & $\begin{array}{l}\text { Alet/araç çok sıcak ya da çok soğuk hale geliyor } \\
\text { mu? }\end{array}$ & 50 & 20.9 & 189 & 79.1 & 4.041 & $.019^{*}$ \\
\hline & Toplam & $1.500 \pm .117$ (7 puan üzerinden) & & & & & 6.923 & $.001^{* *}$ \\
\hline
\end{tabular}

${ }^{*} \mathrm{p}<0.05 * * \mathrm{p}<0.01$

Araç-gereç kullanımından kaynaklanan fiziksel zorlanma ile iş memnuniyeti arasındaki ilişkiye bakıldığında, araç-gereç kullanımı konusunda olumsuz değerlendirme arttıkça bireyin işle ilgili memnuniyet puanının düştüğü belirlenmiștir $(r=$ $.249, \mathrm{p}<0.000)$.

Araç-gereç kullanımında zorlanma ile ilgili her bir maddenin memnuniyet düzeyine göre değerlendirmesi One-Way ANOVA ile yapılmıştır. Varyans analizi sonucunda 4,6 ve 7. maddeler dışındaki 4 maddede araç-gereç kullanımından kaynaklanan zorlanma ile iş memnuniyeti arasındaki ilişki önemsiz (p>0.05) bulunmuştur. Araç-gereç kullanımı ile ilgili zorlanma arttıkça iş memnuniyetinin azaldığı görülmektedir. Alet/araç ağırlığının 4-5 kg'dan fazla olmasının ( $F=3.469$, $\mathrm{p}<0.05$ ), alet/aracın kullanıcıya aşırı geri tepme etkisi yapmasinın $(\mathrm{F}=5.414, \mathrm{p}<0.005)$ ve alet/aracın çok sıcak ya da çok soğuk hale gelmesinin ( $F=4.041$, $\mathrm{p}<0.019$ ) bireyin iş memnuniyetini -maruz kalan bireylerin sayısı az da olsa- etkilediği anlaşılmaktadır. Araç-gereç kullanımında zorlanmaya ilişkin genel değerlendirme puanı ile iş memnuniyeti arasındaki ilişki anlamlıdır $(\mathrm{F}=6.923, \mathrm{p}<0.001)$. Bu sonuç araçgereç kullanımında zorlanma arttıkça iş memnuniyetinin azaldığını göstermektedir.

Çalışma istasyonu ile ilgili olumsuzluk durumu incelendiğinde sonuçlar Tablo 6'da yer almaktadır.

Tablo 6'ya göre "oturma materyali yüksekliğinin işe uygun biçimde ayarlanamadığı (\% 67.8)", "çalışma istasyonunun statik kassal zorlanmayı ya da yüklenmeyi önleyecek biçimde tasarımlanmadı̆̆ı (\% 62.8)", "gereken yerlerde ayak destekleri konulmadığı (\% 63.2)", "çalışma istasyonunun kolların eğilmesi ve bükülmesini önleyecek biçimde (\% 61.5) ve bedenin bükülme (yana) ya da eğilmesini önleyecek şekilde tasarımlanmadığı (\% 59.8)" anlaşılmaktadır.

Buna karşılık çalışma alanının tüm hareketleri yapabilmeye olanak sağladığı $\left(\begin{array}{l}\% \\ 73.2\end{array}\right)$ ve iş ortamında yapılan işe uygun mekanik araç-gereç ve donanımın sağlandığı (\% 76.6) anlaşılmaktadır. Buna ek olarak, bireyin çalışırken pozisyonunu (postürünü) değiştirebildiği, mekanik araç, gereç ve donanım için koruyucu bakım programı uygulandığı, çalışanın el ve kolların çalışma yüzeylerindeki keskin kenarlardan korunduğu görülmektedir. Çalışma istasyonu ile ilgili bu sonuç genellikle çalışma yüksekliklerinin bireysel zorlanmayı artırdığını, eğilme ve bükülmenin fazla olduğunu ve statik kassal zorlanmanın fazla olduğunu ortaya koymaktadır.

Çalışma istasyonu tasarımından kaynaklanan fiziksel zorlanma ile iş memnuniyeti arasındaki ilişkiye bakıldığında, çalışma istasyonu konusunda olumsuz değerlendirme arttıkça bireyin işle ilgili memnuniyet puanının düştügü belirlenmiştir $(\mathrm{r}=.326, \mathrm{p}<0.000)$.

Çalışma istasyonu tasarımından kaynaklanan fiziksel zorlanma ile ilgili her bir maddenin memnuniyet düzeyine göre değerlendirmesi One-Way ANOVA ile yapılmıştır. Varyans analizi sonucunda toplam 9 maddede çalışma istasyonu tasarımından kaynaklanan zorlanma ile iş memnuniyeti arasındaki ilişki önemli $(\mathrm{p}<0.05)$ bulunmuştur. Çalışma yeri tasarımının bireye uygunsuzluğu arttıkça iş memnuniyetinin azaldığı görülmektedir. Genellikle çalışma yerinin açlandırılamadığı, çalışma istasyonunun bükülme (yana) ya da eğilmeye neden olacak şekilde tasarımlandığı, uzanmayı artırdığı, statik kassal zorlanma ve yüklenmeye, kolların ve bileklerin eğilme-bükülmesine neden olduğu görülmektedir. Olumsuzluk yaşayan bireylerde de iş memnuniyetinin azaldığı görülmektedir $(\mathrm{p}<0.05)$. Çalışma istasyonu tasarımından kaynaklanan zorlanmaya ilişkin genel değerlendirme puanı ile iş memnuniyeti arasında da anlamlı ilişki bulunmuştur $(\mathrm{F}=15.223, \mathrm{p}<0.000)$. Bu sonuç çalışma istasyonu tasarımından kaynaklanan zorlanma arttıkça iş memnuniyetinin azaldığını göstermektedir. 
Tablo 6. Bireyin iş ve iş ortamına ilişkin değerlendirmesi: Çalışma istasyonu (n=239)

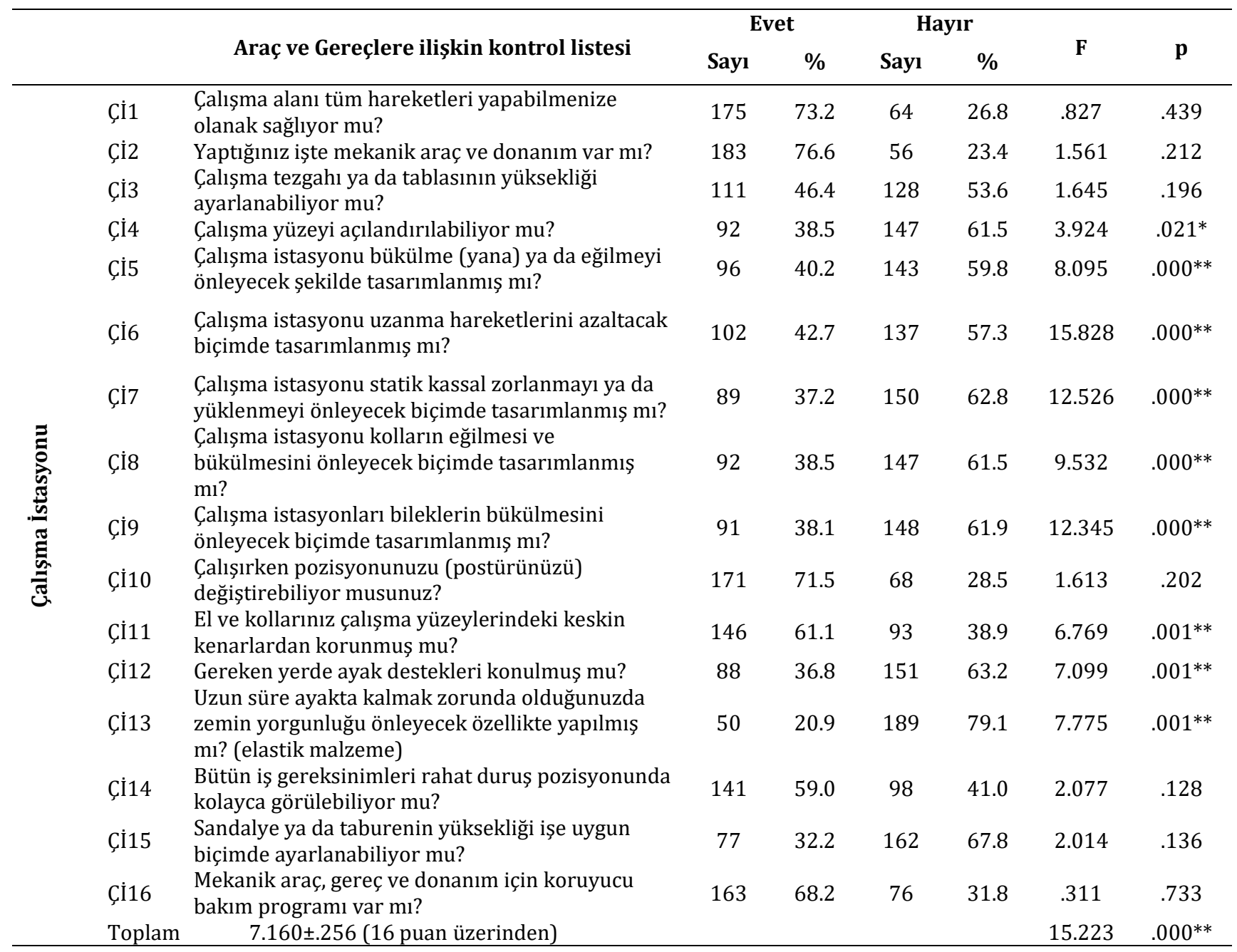

${ }^{*} \mathrm{p}<0.05 * * \mathrm{p}<0.01$

Mobilya ișletmelerinde çalıșma ortamı iș kolaylaştırma açısından incelendiğinde sonuçlar Tablo 7'de yer almaktadır.

Tablo 7'ye göre "işin, beli bükmeden veya bütünüyle eğilmeden yapılamadığı (\% 78.2)”, “sürekli aynı hareketi yapmayı gerektiren işlerde düzenli dinlenme molalarının yanı sıra stresten uzaklaşmayı sağlayacak yeterli dinlenme molalarının verilmediği (\% 64.4)" görülmektedir. Benzer şekilde, "yapılan işi görebilmek için boyun ve omuzların eğilmesinin gerektiği (\% 65.7)" ve yarıdan fazlasında "yapılan işin uzun süre kolları kaldırmayı gerektirdiği (\% 51.0)" anlaşılmaktadır. Buna karşılık, çalışanların yarıdan çoğu "işin, göz yorulması veya kamaşmasına neden olmadan yapılabildiğini (\% 54.4)", "alet, avadanlı ve makinelerin işin rahat bir pozisyonda kullanılabileceği şekilde yapıldığı ve yerleștirildiğini (\% 64.9)" ve "işin, vücudun daha büyük kaslarını kullanarak yapılabildiğini (bacak ve kol kasları gibi) (\% 54.4)" belirtmişlerdir.

İş kolaylaştırma ile ilgili önlemlerin alınmamasından kaynaklanan fiziksel zorlanma ile iş memnuniyeti arasındaki ilişkiye bakıldığında, iş kolaylaştırma konusunda olumsuz değerlendirme arttıkça bireyin işle ilgili memnuniyet puanının düştüğü belirlenmiştir $(r=.161, \mathrm{p}<0.019)$.

İş kolaylaştırma ile ilgili önlemlerin alınmamasından kaynaklanan fiziksel zorlanma ile ilgili her bir maddenin memnuniyet düzeyine göre değerlendirmesi One-Way ANOVA ile yapılmıștır. Varyans analizi sonucunda 7, 8 ve 9. maddelerde iş kolaylaştırma ile ilgili önlemlerin alınmamasından kaynaklanan zorlanma ile iş memnuniyeti arasındaki ilişki önemli $(\mathrm{p}<0.05)$ bulunmuştur. Alınan önlemler azaldıkça iş memnuniyetinin de azaldığ görülmektedir. Sürekli aynı hareketi yapmayı gerektiren işlerde düzenli dinlenme molalarının yanı sıra stresten uzaklaşmayı sağlayacak yeterli dinlenme molaları verilmediği, mobilyaların vücudun yorulmasını asgariye indirecek şekilde ayarlanmadı̆̆g, yerleştirilmediği ve düzenlenmediği görülmektedir. Buna karşılık çalıșanların yarıdan çoğu (\% 64.9) aletler, avadanlıklar ve makinelerin işin rahat bir pozisyonda yapılabileceği şekilde yapıldığını ve yerleştirildiğini ifade etmişlerdir. Olumsuzluk yaşayan bireylerde iş memnuniyetinin azaldığı görülmektedir $(\mathrm{p}<0.05)$. 
Tablo 7. Bireyin iş ve iş ortamına ilişkin değerlendirmesi: İş kolaylaştırma $(n=239)$

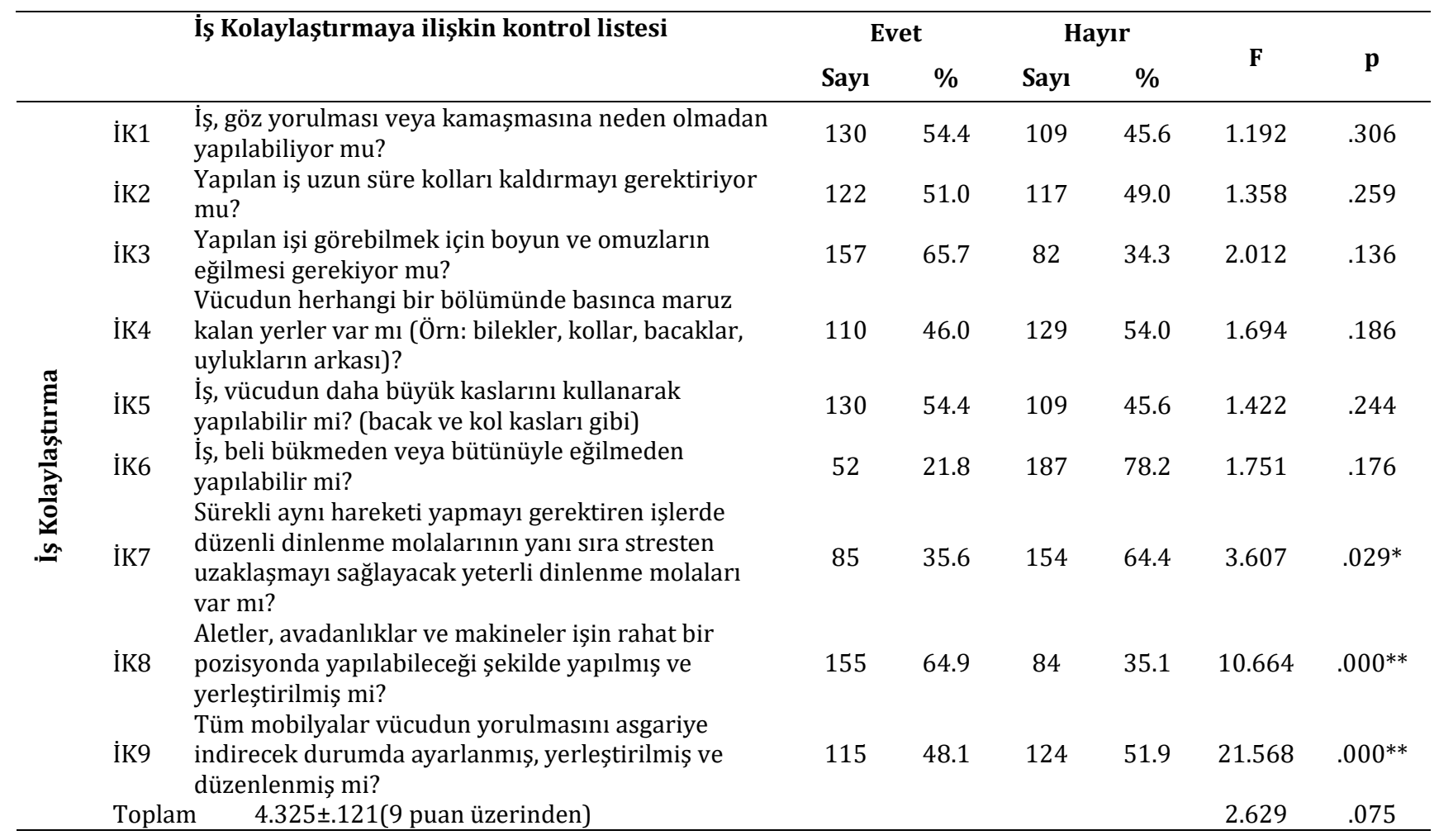

${ }^{*} \mathrm{p}<0.05 * * \mathrm{p}<0.01$

İş kolaylaştırma ile ilgili önlemlerin alınmamasından kaynaklanan zorlanmaya ilişkin genel değerlendirme puanı ile iş memnuniyeti arasında anlamlı bir ilişki bulunmamıştır ( $\mathrm{p}>0.05)$.

\section{5.İş ve is ortamına ilişkin değerlendirmeler üzerinde bazı değişkenlerin etkileri}

Farklı birimlerde çalışan bireylerin iș ve iş ortamı ile bedensel zorlanmaları üzerinde diğer değișkenlerin (çalışılan birim, yaş, sigara kullanma durumu, sağlık durumu, bedensel zorlanma, memnuniyet puanı) etkisi de araştırılmıştır.

Farklı birimlerde çalışan bireylerin iş ve iş ortamına ilişkin değerlendirmeleri varyans analizi ile değerlendirilmiş sonuçlar Tablo 8'de verilmiştir.

Tablo 8. Farklı birimlerde çalıșan bireylerin iș ve iş ortamına ilişkin değerlendirmeleri (One-way ANOVA)

\begin{tabular}{|c|c|c|c|}
\hline $\begin{array}{l}\text { İş ortamına ilişkin } \\
\text { değerlendirme }\end{array}$ & $\begin{array}{l}\text { Kareler } \\
\text { toplamı }\end{array}$ & $\mathbf{F}$ & $\mathbf{p}$ \\
\hline Elle çalışma (sd=7) & 86,514 & 4,151 & $.000^{* *}$ \\
\hline $\begin{array}{l}\text { Fiziksel enerji } \\
\text { tüketimi }\end{array}$ & 87,769 & 2,033 & $.052^{*}$ \\
\hline $\begin{array}{l}\text { Kas-iskelet sistemi } \\
\text { kullanımı }\end{array}$ & 43,152 & 1,646 & .123 \\
\hline Araç ve gereçler & 44,826 & 2,213 & $.034^{*}$ \\
\hline Çalışma istasyonu & 142,362 & 1,374 & .217 \\
\hline İș kolaylaştırma & 28,476 & 1,236 & .284 \\
\hline Toplam & 1187,101 & 2,219 & $.034^{*}$ \\
\hline
\end{tabular}

Tablo 8'e göre elle çalışma $(F=4,151, p<0.001)$, fiziksel enerji tüketimi $(\mathrm{F}=2,033, \mathrm{p}<0.052)$, araç ve gereçler $(\mathrm{F}=2,213, \mathrm{p}<0.034)$ ile toplam değerlendirmeler $(\mathrm{F}=2,219, \quad \mathrm{p}<0.034)$ arasinda farklılı bulunmuștur. İș ortamı çalıșılan birime göre değerlendirildiğinde en fazla zorlanma paketleme işleminde olmakta, bunu sırası ile zımparalama, vernik-boya uygulamaları izlemektedir. Mobilya işletmelerinde masif işleme en az zorlanılan iş olarak görülmektedir. Çalışanların yaşı ve sigara kullanma durumu iș ve iș ortamına ilișkin değerlendirmede farklılık göstermemektedir ( $\mathrm{p}>0.05)$. Buna karşılık "kas ve iskelet sistemi kullanımı" ile ilgili olumsuz değerlendirmeler sağlı sorunu olan bireylerde önemlidir $(\mathrm{p}<0.05)$.

Benzer şekilde, yapılan $\mathrm{t}$ testi sonucunda bedensel zorlanma ile fiziksel enerji tüketimi $(\mathrm{t}=3.114$, $\mathrm{p}<.002)$, kas-iskelet sistemi kullanımı $(\mathrm{t}=4.888$, $\mathrm{p}<.000)$, işte kullanılan araç ve gereçler $(\mathrm{t}=2.286$, $\mathrm{p}<.023)$, çalışma istasyonu $(\mathrm{t}=-2.526, \mathrm{p}<.012)$ ve iş kolaylaştırmaya $\quad(\mathrm{t}=-2.007, \quad \mathrm{p}<.046) \quad$ ilişkin değerlendirme arasındaki ilişki önemlidir. Bu sonuca göre memnuniyetsizliğin temel kaynağı iş ve iş ortamının bireye uygun olmaması, bedensel zorlanmayı artırmasıdır. $\mathrm{Bu}$ da olumsuz değerlendirmelerin bireysel özelliklerden çok, ortamın kendisi ve işin zorluğu ile ilgili olduğunu göstermektedir.

İş değerlendirme puanı toplamı çalışanların \% 6.3'ünde 15 puan ve altındadır ve bu bireyler çalışma koşullarının çok ağır olduğunu ve fiziksel olarak 
zorlandıklarını belirtmişlerdir. Çalışma koşullarını orta olarak niteleyenler (16-30 puan) \% 51.5, iyi olarak niteleyenler (31-45 puan) \% 39.7 oranındadır. Çalışma koşullarını olumlu olarak niteleyenlerin (46+ puan) oranı ise $\% 2.5^{\prime}$ tir.

İşten memnuniyet puanı çalışanların \% 29.4'ünde 5 puan ve altındadır (memnun olmayan ve hiç memnun olmayanlar), 6-7 puan arasinda olanlar \% 34.6 (orta derecede memnun olanlar), 8+ puan olanlar ise \% 36.0 (memnun ve çok memnun olanlar) oranındadır.

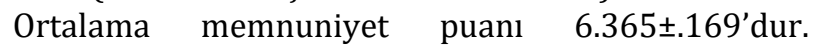
Çalışma ortamı ile işten memnuniyet arasındaki ilişkiye bakıldığında çalışma ortamı koşulları iyileştikçe memnuniyetin arttığı $(F=21.430, p<0.001)$ görülmektedir. Yapılan korelasyon analizinde de çalışma ortamı ile işten memnuniyet arasında yüksek korelasyon $(\mathrm{r}=-.436, \mathrm{p}<0.001)$ belirlenmiştir. Sonuç olarak iş ve ortam koşulları iyileştikçe iş yaşamından memnuniyet artmaktadır.

\section{Sonuç}

Araştırma sonuçları araştırma kapsamına alınan işletmelerde çalışan bireylerde zorlanma olduğunu, işin fiziksel olarak ağır ve ayakta çalışmayı gerektirdiğini, uygun olmayan çok fazla postür olduğunu, çalışma hızının yüksek ve tekrarlı hareketlerin fazla olduğunu ortaya koymaktadır. Çalışanların iş ve iş ortamına ilişkin olumsuz değerlendirmeleri arttıkça elle çalışma, fiziksel enerji tüketimi, kas-iskelet sistemi kullanımı, işte kullanılan araç ve gereçler, çalışma istasyonu ve iş kolaylaştırmaya ilişkin memnuniyetleri azalmaktadır. İş ortamı koşullarının iyileștirilmesi ve fiziki konforun artırılması insani bir gerekliliktir. $\mathrm{Bu}$ durum aynı zamanda kassal zorlanma ve fiziksel enerji tüketimini azaltarak, bireyin iş memnuniyetinin artmasını da sağlayacaktır.

Bundan sonra yapılacak çalışmalarda, çalışma ortamında insan-makine ve insan-çevre ilişkilerinin ergonomi prensipleri doğrultusunda belirlenmesinin gereği dikkate alınmalıdır. Böylece ișin insansal maliyetinin minimuma indirilmesi, yorulma ve zorlanmanın azaltılması ile iş verimliliği ve memnuniyetin artması mümkün olabilecektir. Benzer şekilde kas-iskelet sistemi kaynaklı sağlık sorunlarının azalması ve ortadan kaldırılması da bireyin yaşam kalitesini artırdığ gibi işe devamsızlığı azaltarak verimliliğin ve üretkenliğin artmasına katkı sağlayacaktır.

\section{Çıkar Çatışması}

Yazarlar tarafından herhangi bir çıkar çatışması beyan edilmemiştir.

No conflict of interest was declared by the authors.

\section{Kaynaklar}

Ahasan, M.R., Vayrynen, S. \& Kirvesoja, H. 1996. Physical workload analysis among small industry activities using postural data. International Journal of Occupational Safety and Ergonomics, 2(1):27-34.

Anon, 2011. Managing the Work Environment and Facilities. Safe Work Australia, https://www. safework.sa.gov.au/uploaded files/CoPManaging WorkEnvironmentFacilities.pdf

Bielski, J., Wolowicki, J. \& Zeyland, A. 1976. The ergonomic evaluation of work stress in the furniture industry. Applied Ergonomics, 7(2):8991.

Bugajska, J., Zołnierczyk-Zreda, D., Jedryka-Goral, A., Gasik, R., Hildt-Ciupinska, K., Malinska, M. \& Bedynska, S. 2013. Psychological factors at work and musculoskeletal disorders: a one year prospective study. Rheumatol Int, 33:2975-2983. DOI 10.1007/s00296-013-2843-8

Bullock, M. 1994. Research to optimise human performance. Australian Physiotherapy, 40:5-17.

Cheung, J.P.Y., Fung, B., Ip, W.Y. \& Chow, S.P. 2008. Occupational repetitive strain injuries in Hong Kong. Hong Kong Med J, 14(4):296-302.

Commissaris, D., Douwes, M., Schoenmaker, N. \& de Korte, E. 2006. Recommendations for sufficient physical activity at work. Proc. Congress (IEA). http://tools.nisb.nl/beleidsinstrumenten/bravokompas/bewegen/tno_kvl_richtlijnen_voldoende_ bewegen_op_werk.pdf

Dababneh, A., Lowe, B., Krieg, E., Kong, Y.K. \& Waters, T. 2004. Ergonomics. A checklist for the ergonomic evaluation of nonpowered hand tools. J Occup Environ Hyg, 1(12):135-45.

David, G., Woods, V., Li, G. \& Buckle, P. 2008. The development of the Quick Exposure Check (QEC) for assessing exposure to risk factors for workrelated musculoskeletal disorders. Applied Ergonomics, 39:57-69.

Davis, K.G. \& Heaney, C.A. 2000. The relationship between psychosocial work characteristics and low back pain: Underlying methodological issues. Clinical Biomechanics, 15:389-406.

Devereux, J., Rydstadt, L., Kelly, V., Weston, P. \& Buckle, P. 2004. The role of work stress and psychological factors in the development of musculoskeletal disorders. Robens Centre for Health Ergonomics for the Health and Safety Executive. Guildford.

Eurofound, 2012. Furniture Sector: Working Conditions and Job Quality. European Foundation 
for the Improvement of Living and Working Conditions. EF/13/84/EN 9. Dublin, Ireland.

Falaki, H., Motallebi, K., Bahrami, A., Sarsangi, V., Akbari, H. \& Rahimizadeh, A. 2014. Prevalence of musculoskeletal disorders and related risk factors among the water-counter manufacturer workers. Quarterly of International Archives of Health Sciences, 1(1):15-20.

Ferguson, S.A., Allread, W.G., Burr, D.L., Heaney, C.A. \& Marras, W.S. 2012. Biomechanical, psychosocial and individual risk factors predicting low back functional impairment among furniture distribution employees. Clinical Biomechanics, 27:117-123.

Ferreira, J., Gray, M., Hunter, L., Birtles, M. \& Riley, D. 2009. Development of an Assessment Tool for Repetitive Tasks of the Upper Limbs (ART). Derbyshire: HSE Books.

Hameed, A. \& Amjad, S. 2009. Impact of office design on employees' productivity: A case study of banking organizations of Abbottabad, Pakistan. Journal of Public Affairs, Administration and Management, 3(1):1-13.

HSE, 2013. Ergonomics and human factors at work: A brief guide. http://www.hse.gov.uk/pubns/indg 90.pdf

İPAS. 2007. Türkiye Geneli 2007 Yılı İşgücü Piyasası Araştırma Sonuç Raporu. Ankara.

Karasek, R. A. Jr. 1979. Job demands, job decision latitude, and mental strain: Implications for job redesign. Administrative Science Quarterly, 24:285-308.

Labaj, A., Diesbourg, T., Dumas, G., Plamondon, A.,
Mercheri, H. \& Larue, L. 2016. Posture and lifting exposures for daycare workers. International Journal of Industrial Ergonomics, 54:83-92.

Mirka, G.A. 2005. Development of an ergonomics guideline for the furniture manufacturing industry. Applied Ergonomics 36:241-247.

Nejad, N.H., Choobineh, A., Rahimifard, H., Haidari, H.R. \& Tabatabaei, S.H.R. 2013. Musculoskeletal risk assessment in small furniture manufacturing workshops. International Journal of Occupational Safety and Ergonomics (JOSE), 19(2):275-284.

Niskanen, T. 1985. Accidents and minor accidents of musculoskeletal systems in heavy and light construction work. Journal of Occupational Accidents, 7: 17-32.

Nunes, I.L. \& Bush, P.M. 2012. Work-related musculoskeletal disorders assessment and prevention. (ed: I.L. Nunes). Ergonomics - A Systems Approach. Rijeka, Croatia. (pp.1-30).

Van der Molen, H.F., Sluiter, J.K., Hulshof, C.T.J., Vink, P. \& Frings-Dresen, M.H.W. 2005. Effectiveness of measures and implementation strategies in reducing physical work demands due to manual handling at work. Scandinavian Journal of Work, Environment \& Health, 31(2):75-87.

Vieira, E.R. \& Kumar, S. 2004. Working postures: A literature review. Journal of Occupational Rehabilitation, 14(2):143-159.

Wickstrom, G., Niskanen, T. \& Riihimaki, H. 1985. Strain on the back in concrete reinforcement work. British Journal of Industrial Medicine, 43: 233-239. 